\title{
BONE TUNNEL ENLARGEMENT WITH NON-METALLIC INTERFERENCE SCREWS IN ACL RECONSTRUCTION
}

\section{ALARGAMENTO DOS TÚNEIS ÓSSEOS NA RECONSTRUÇÃO DO LCA COM PARAFUSOS DE INTERFERÊNCIA NÃO METÁLICOS}

\author{
Vitor Barion Castro de Padua ${ }^{1,2}$, Júlio Cesar rodrigues Vilela ${ }^{1,2}$, Wendel Aculha Espindola ${ }^{1,2}$, Rafael Cassiolato Garcia Godor ${ }^{1,2}$ \\ 1. Associação Beneficiente Hospital Universitário (ABHU), Marília, SP, Brazil. \\ 2. Clínica Traumato-Ortopédica Prof. Dr. Hilário Maldonado, Marília, SP, Brazil.
}

\section{ABSTRACT}

Objective: To compare the widening of bone tunnels between poly- etheretherketone (PEEK), absorbable polylactic acid DL (PLDL) and tricalcium phosphate (TCP) interference screws in anterior cruciate ligament $(\mathrm{ACL})$ reconstruction. Methods: Three groups of patients undergoing ACL reconstruction with at least 1 year of follow-up using the out-in drilling technique and hamstring as a graft were assessed. The patients were divided according to the type of interference screw used (PEEK, PLDL and TCP). Computed tomography (CT) was performed to measure the greatest femoral and tibial tunnel widening regarding to the initial tunnel, and then it was compared between groups. Results: Mean widening in group 1 (PEEK) was 39.56\% (SD 16\%) in the femoral tunnel and 33.65\% (SD 20\%) in the tibia. In group 2 (PLDL) mean widening was $48.43 \%$ in the femoral tunnel (SD 18\%) and $35.24 \%$ (SD 13\%) in the tibial tunnel. In group 3 (TCP) mean widening was $44.51 \%$ in the femur (SD 14\%) and $36.83 \%$ in the tibia (SD 14\%). The comparison between groups (PLDL-PEEK, PLDLTCP, PEEK-TCP) shows no statistically significant difference. Conclusion: Bone tunnel enlargement values after ACL reconstruction with the use of different types of materials (bioinert and biomaterials) of interference screws (PEEK, PLDL and TCP) were similar. Level of Evidence III, Comparative retrospective study.

Keywords: Anterior cruciate ligament reconstruction. Hamstring tendons.

\section{RESUMO}

Objetivo: Comparar o alargamento dos túneis ósseos entre parafusos de interferência de poli-éter-etil-cetona (PEEK), ácido poli lático (PLDL) absorvível e tricálcio fosfato (TCP) na reconstrução do ligamento cruzado anterior (LCA). Métodos: Foram avaliados três grupos de pacientes submetidos à reconstrução do LCA com ao menos um ano de acompanhamento, com perfuração de fora para dentro, tendões flexores quádruplos como enxerto, que foram divididos de acordo com o parafuso de interferência utilizado (PEEK, PLDL e TCP). Realizou-se tomografia computadorizada (TC) para aferição do maior alargamento do túnel tibial e femoral em relação ao túnel inicial, e foi comparado o alargamento entre os grupos. Resultados: O alargamento médio no grupo 1 (PEEK) foi 39,56\% (DP = 16\%) no túnel femoral e 33,65\% (DP = 20\%) na tíbia. No grupo 2 (PLDL) o alargamento médio do túnel femoral foi 48,43\% $(D P=18 \%)$ e $35,24 \%(D P=13 \%)$ na tíbia. No grupo $3(T C P) 44,51 \%$ $(D P=14 \%)$ foi o alargamento médio no fêmur e 36.83\% (DP = 14\%) na tíbia. Na comparação entre os grupos (PLDL-PEEK, PLDL-TCP, PEEK-TCP) não houve diferença estatisticamente significante. Conclusão: $O$ alargamento dos túneis ósseos após a reconstrução do LCA com a utilização de diferentes tipos de materiais (bioinertes e biomateriais) de parafusos de interferência (PEEK, PLDL e TCP) foi semelhante. Nível de Evidencia III, Estudo retrospectivo comparativo.

Descritores: Reconstrução do ligamento cruzado anterior. Tendões dos isquiotibiais.

Citation: Padua VBC, Vilela JCR, Espindola WA, Godoy RCG. Bone tunnel enlargement with non-metallic interference screws in acl reconstruction. Acta Ortop Bras. [online]. 2018;26(5):305-8. Available from URL: http://www.scielo.br/aob.

\section{INTRODUCTION}

Anterior cruciate ligament (ACL) reconstruction is performed for professional and recreational athletes and in cases of daily life instability. The ligament reconstruction techniques, with the anatomical positioning of the graft, leads to good results with the use of different methods and fixation devices. ${ }^{1}$

The interference screw is still the most widely used fixation, ${ }^{2}$ and is made from many different types of materials, such as titanium, bioinert materials such as polyether-ethyl ketone (PEEK), and bioabsorbable materials, such as poly-lactic acid (PLDL) that may be associated with biocomposites, such as hydroxyapatite $(H A)$, and tricalcium phosphate (TCP), each with their advantages and disadvantages. . $^{3,4}$,

Metal (titanium) interference screws, although widely used due to their lower cost, have some disadvantages such as the difficulty of being removed in a revision surgery ${ }^{3,4}$ and the presence of

All authors declare no potential conflict of interest related to this article.

Work conducted at the Associação Beneficiente Hospital Universitário (ABHU), Marília, SP, Brazil.

Correspondence: Vitor Barion Castro de Padua. Av Esmeraldas, 3023, Jd Esmeraldas, Marília, SP, Brazil. 17516-000. drvitorpadua@gmail.com 
artifacts in magnetic resonance imaging (MRI) that may hamper a correct interpretation, which directed several surgeons to opt for screws made of bioinert materials and biomaterials. ${ }^{5}$

According to the literature, regardless the screw material, the surgical outcomes are similar. ${ }^{3}$ Some authors, however, have questioned the use of biomaterials, which could cause local inflammation during their absorption, leading to an enlargement of the bone tunnels. ${ }^{5,6}$

However, this enlargement has multifactorial causes ${ }^{7}$ and does not interfere with the clinical outcome, ${ }^{1,5,8,9}$ it occurs also with the use of non-absorbable screws, and in extracortical fixation, without material inside the bone tunnel, like the "EndoButton".10

The objective of this study is to compare the enlargement of bone tunnels one year after ACL reconstruction, with computed tomography (CT), among three types of interference screws: pure poly-lactic acid (PLDL), absorbable poly-lactic acid with tricalcium-phosphate (TCP), and polyether-ethylketone (PEEK). We hypothesize that the enlargement of the bone tunnels among the raw materials of interference screws is similar, which would be a safety factor for the use of biomaterials.

\section{MATERIALS AND METHODS}

Three groups of patients were retrospectively selected one year after $A C L$ reconstruction and divided according to the type of interference screw used (PLDL, TCP, or PEEK).

The inclusion criteria consisted of patients aged between 18 and 55 years who presented with an ACL injury, confirmed by MRI, with complaints of instability for physical activity or in daily life, with a positive Lachman and/or Pivot Shift test, and were submitted to ACL reconstruction, by drilling technique of tunnels from outside in (OUT-IN), with the hamstring as a graft by the same surgeon. ACL reconstruction was performed by a drilling technique (OUT- IN) according to Chambat, ${ }^{11}$ but with quadruple hamstring keeping the distal insertion on the tibia. Once prepared, the graft was passed from the distal to proximal and fixed with interference screws of the same diameter of the tunnel, first in the tibia and subsequently in the femur, from outside in, at $30^{\circ}$ of flexion. ${ }^{12}$

Remnants of the ACL, when present, were preserved and the graft routed through the remnant.

No immobilization was used, patients were instructed to initiate active contraction of the quadriceps soon after the procedure and were discharged the following day with progressive partial load with the aid of crutches for two weeks.

The physiotherapy program was started on the second postoperative day, total range of motion in 4-6 weeks, running at 12 weeks, and return to sport activities after 6 months.

No patients experienced complications related to the surgical technique. Patients who underwent associated procedures during the same surgery such as osteotomy or multi-ligamentous injury, and patients with pre-existing tunnels, were excluded.

A total of three non-randomized groups were analyzed. Group 1: 20 patients with PEEK interference screws (Masterteck-BIOTECK); group 2: 20 patients with absorbable poly-lactic acid (PLDL) screws (Sinfix-SINTEGRA) and group 3: 10 patients with PLDL absorbable screws with tricalcium phosphate (TCP) (Sinfix-SINTEGRA).

The average age of the groups, was 34.85 years in the PEEK group, and 37.05 and 36.2 years in the PLDL and TCP groups, respectively. The gender of patients was $85 \%$ males in the PLDL group, $80 \%$ in the PEEK group, and $90.0 \%$ in the TCP group, as shown in Table 1. Non-contrast CT scan was performed using a Toshiba Aquilion CXL 128-channel device with $0.5 \mathrm{~mm}$ cuts. In the coronal, sagittal, and oblique incidences, the region of greatest enlargement of the femoral and tibial tunnel was located, and through the axial section, this enlargement was measured and compared to the size of the initial femoral and tibial tunnel performed during surgery. The measurements were performed by two evaluators who were unaware of the type of screw used and the average between them was taken into account. (Figure 1)

\begin{tabular}{|c|c|c|c|}
\hline Group & Mean age & $\begin{array}{l}\text { Male } \\
\mathrm{N}(\%)\end{array}$ & $\begin{array}{c}\text { Female } \\
\mathrm{N}(\%)\end{array}$ \\
\hline PEEK & 34.85 & $16(80 \%)$ & $4(20 \%)$ \\
\hline PLDL & 37.05 & $17(85 \%)$ & $3(15 \%)$ \\
\hline TCP & 36.2 & $9(90 \%)$ & $1(10 \%)$ \\
\hline
\end{tabular}

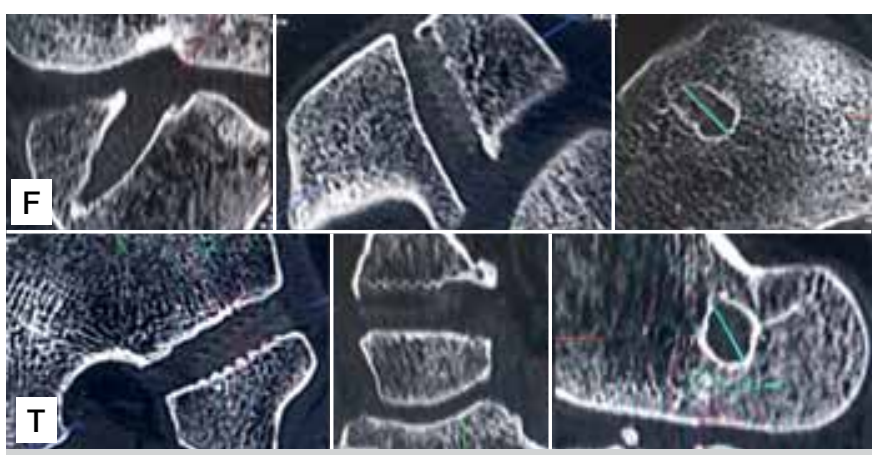

Figure 1. Measure of the enlargement of the femoral $(F)$ and tibial (T) tunnel.

\section{Statistical analysis}

The statistical analysis was performed using the Student's t-test, adopting a confidence interval of $95 \%(p=0.05)$.

\section{RESULTS}

The three non-randomized groups evaluated in our study were: Group 1: 20 patients (80\% male) in which PEEK (Masterteck-BIOTECK) interference screws with mean age 34.85 years, group 2: 20 (85\% male) with polylactic acid (PLDL) absorbable screws (Sinfix-SINTEGRA) with a mean age of 37.05, and group 3: 10 patients (90\% male) with PLDL absorbable screws with tricalcium phosphate (TCP) (Sinfix-SINTEGRA) and with a mean age of 36.2 years. There was no statistically significant difference between sex and age among the groups according to the ANOVA analysis with $95 \% \mathrm{Cl}$.

The average enlargement in group 1 (PEEK) was 39.56\% (SD $16 \%$ ) in the femoral tunnel and 33.65\% (SD 20\%) in the tibia. In group 2 (PLDL), the average enlargement of the femoral tunnel was $48.43 \%$ (SD 18\%) and 35.24\% (SD 13\%) in the tibia. In group 3 (TCP), the enlargement on the femur was $44.51 \%$ (SD 14\%) and $36.83 \%$ (SD14\%) in the tibia (Table 2).

The comparison between groups was performed with a confidence interval of $95 \%(p=0.05)$. The values of femoral and tibial tunnels enlargement compared between the groups (PEEKX PLDL, PEEK X TCP, PLDL X TCP), didn't show statistically significant difference.

\section{DISCUSSION}

In our study, the comparison of the enlargement of the bone tunnels between the different types of non-metallic materials of interference screws evaluated was similar. There are biological and mechanical hypotheses of bone tunnels enlargement after ACL reconstruction. Some of the biological factors include the inflammatory response to the graft, necrosis from bone drilling, synovial fluid within the 
Table 2. Enlargement of the tunnels.

\begin{tabular}{c|c|c}
\hline Group & Enlargement in the femur & Enlargement in the tibia \\
\hline PEEK & $39.65 \%$ & $33.65 \%$ \\
\hline PLDL & $48.10 \%$ & $35.24 \%$ \\
\hline TCP & $44.51 \%$ & $36.83 \%$ \\
\hline
\end{tabular}

tunnel, and absorption of the intra-tunnel material. ${ }^{1,13}$ Accelerated rehabilitation, the "windshield-wiper" and the "bungee cord" effect due to the movement of the graft inside the tunnel and incorrect positioning of the tunnels are mechanical hypotheses. $5,10,13 \mathrm{Xu}^{1}$ found that the anterior, proximal, and vertical positioning of the femoral tunnel leads to a greater enlargement of the tunnels in both the femur and the tibia.

Some studies show greater enlargement of the tunnels with the use of indirect fixation, such as the extracortical "EndoButton" compared with the fixation within the tunnel as the interference screw. ${ }^{8,13}$

However, Fauno ${ }^{10}$ compared extracortical and direct fixation and found no significant difference between the two methods.

It is believed that the greatest enlargement of the tunnels occurs within the first postoperative year ${ }^{5,10}$ with little to no change in the time following. Webster ${ }^{14}$ mentions that the enlargement found within the fourth month after the surgery was the same as at one and two years postoperatively, while Fink ${ }^{15}$ found the greatest enlargement in the first six weeks. We opted for an evaluation at one year postoperatively because the enlargement would already have been established.

The measurement of tunnel enlargement can be performed through digital radiography ( $\mathrm{RX}), \mathrm{CT}$, and magnetic resonance imaging (MRI), and although some authors report that all methods are similar $8,10,14$ we opted for the CT as being more precise ${ }^{16}$ on the location of the margin of the tunnel sclerosis.

The measure of the enlargement can be performed $2 \mathrm{~cm}$ from the articulate edge, ${ }^{5}$ on the articulate edge, ${ }^{7}$ on the widest and central part of the tunnel, and usually in two radiological imaging planes ${ }^{1}$ or by the total area of the increase volume of the tunnel. ${ }^{3,13}$

We use three CT plans (sagittal, coronal, and oblique) to identify the location of greatest enlargement of the tunnel, and we measured the enlargement on this site in the axial plane.

The material of the absorbable interference screw can influence the enlargement of the bone tunnel due to formation of an inflammatory process during its absorption. ${ }^{4}$ Moisala ${ }^{6}$ found that PLDL compared with metal screws led to greater enlargement of the femoral tunnel. The average widening of the tunnels within the three types of interference screws evaluated in our study showed that PEEK, a bioinert material with no absorption, led to a smaller tunnel expansion, but it was statistically similar to biomaterials, such as PLDL and TCP.

It is believed that the addition of biocomposites, such as tricalcium phosphate (TCP) and hydroxyapatite (HA) in PLDL, can accelerate the process of graft incorporation with improved conversion to cancellous bone which reduces acidity during degradation. ${ }^{17}$ Lee $^{4}$ using MRI, compared the enlargement of the tibial tunnel between PLDL with hydroxyapatite (HA) and pure PLDL screws and found a smaller tibial tunnel enlargement (27.4\% x 41.3\%), similar to Robinson ${ }^{18}$ who also found a smaller tibial tunnel enlargement using CT, 29.9\% with the addition of HA to PLDL compared to pure PLDL 46\%. In our study, the screw with biocomposite (TCP) showed a $36.83 \%$ enlargement of the tibial tunnel, close to studies with addition of HA., ${ }^{4,18}$ However, in the group with pure PLDL, enlargement of the tibial tunnel (35.24\%) was slightly lower than the TCP group, unlike most studies. ${ }^{4,17,18}$
Wang ${ }^{19}$ found a greater enlargement in the TCP group compared with the pure PLDL group, in the region of the tunnel without the presence of the screw, believing it to be due to a cellular response of tricalcium-phosphate degradation, which generates particles that activate osteoclasts, similar to debris in aseptic loosening of arthroplasties. However, the region of the tunnel without the screw is an area susceptible to the "windshield-wiper" effect, which can lead to a further enlargement due to the movement of the graft. We did not evaluate the position of the screw inside the tunnel, but we were able to observe in some cases, that the greatest enlargement was near to the articular exit of the tunnel without the presence of the screw (Figure 2).

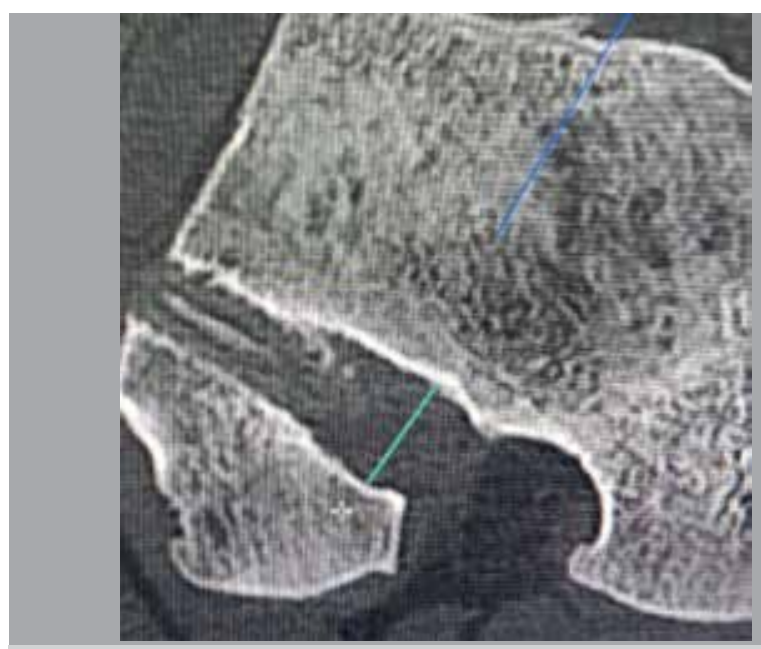

Figure 2. Enlargement in the area without a screw.

The variation on the composition of the bioabsorbable material of each screw used in the different studies, such as the percentage of dextrorotatory acid and levorotatory acid in the PLDL screws, and the different percentages of TCP added to the PLDL should also be considered, which may influence the speed of degradation and osseointegration of the material, and was not evaluated in our study. Our study did not evaluate the absorption of the material of the screw (screw volume inside the tunnel), or the filling of the tunnel by bone tissue, which, according to the literature, occurs more intensely on the TCP screw due to osteoinduction properties. ${ }^{19}$

In our study, we did not differentiate patients in whom the remnants of the ACL were preserved, which could reduce the intra-tunnel synovial liquid and change the enlargement. ${ }^{20}$ However, Hwang ${ }^{13}$ compared ACL reconstruction with the hamstring and press-fit fixation, believing that this would reduce the intra-tunnel synovial fluid and would have a smaller increase of the total tunnel volume, but no difference was found compared to the conventional technique. Although the enlargement of the bone tunnels is common in ACL reconstruction and has no correlation with the clinical outcome $e^{5,8,9}$ we did not compare clinically the patients among the different groups. One limitation of our study was that the TCP group had a smaller number of patients compared to the other groups.

Further analysis should be conducted with a longer follow-up, observation of the screw positioning inside the tunnel and the enlargement around the screw during the absorption of biomaterials.

\section{CONCLUSION}

$A C L$ reconstruction using interference screws made of biomaterials with or without biocomposites (pure PLDL and with TCP) and bioinert materials (PEEK) showed a similar enlargement of the bone tunnels, without a statistically significant difference. 
AUTHORS' CONTRIBUTIONS: Each author made significant individual contributions to this manuscript. VBCP (0000-0002-9479-7764)*: drafting of the article, revision, intellectual concept of the article and production of the entire research project, bibliographic review and performance of the surgeries; JCRV (0000-0002-4462-2536)*: drafting of the article, revision, statistical analysis, intellectual concept of the article and production of the entire research project and collection of data; WAE (0000-0003-1178-4472)*: surgeries, collection of data and revision of the article; RCGG (0000-0002-1561-4502)*: surgery and revision of the article. *ORCID (Open Researcher and Contributor ID).

\section{REFERENCES}

1. Xu Y, Ao Y, Wang J, Yu J, Cui G. Relation of Tunnel Enlargement and Tunnel Placement After Single-Bundle Anterior Cruciate Ligament Reconstruction. Arthroscopy. 2011;27(7):923-32.

2. Laxdal G, Kartus J, Eriksson BI, Faxén E, Sernert N, Karlsson J. Biodegradable and metallic interference screws in anterior cruciate ligament reconstruction surgery using hamstring tendon grafts: prospective randomized study of radiographic results and clinical outcome. Am J Sports Med. 2006;34(10):1574-80.

3. Bach FD, Carlier RY, Elis JB, Mompoint DM, Feydy A, Judet O, et al. Anterior Cruciate Ligament Reconstruction with Bioabsorbable Polyglycolic Acid Interference Screws: MR Imaging Follow-up. Radiology. 2002;225(2):541-50.

4. Lee DW, Lee JW, Kim SB, Park JH, Chung KS, Ha JK, et al. Comparison of Poly-L-Lactic Acid and Poly-L-Lactic Acid/Hydroxyapatite Bioabsorbable Screws for Tibial Fixation in ACL Reconstruction: Clinical and Magnetic Resonance Imaging Results. Clin Orthop Surg. 2017;9(3):270-9.

5. Uzumcugil O, Yalcinkaya M, Ozturkmen Y, Dikmen G, Caniklioglu M. Effect of PEEK Polymer on Tunnel Widening After Hamstring ACL Reconstruction. Orthopedics. 2012;35(5):e654-9.

6. Moisala AS, Jarvela T, Paakkala A, Paakkala T, Kannus P, Jarvinen M. Comparison of the bioabsorbable and metal screw fixation after ACL reconstruction with a hamstring autograft in MRI and clinical outcome: a prospective randomized study. Knee Surg Sports Traumatol Arthrosc. 2008;16(12):1080-6.

7. Siebold R. Observations on Bone Tunnel Enlargement After Double-Bundle Anterior Cruciate Ligament Reconstruction. Arthroscopy. 2007;23(3):291-8.

8. Buelow JU, Siebold R, Ellermann A. A prospective evaluation of tunnel enlargement in anterior cruciate ligament reconstruction with hamstrings: Extracortical versus anatomical fixation. Knee Surg Sports Traumatol Arthrosc. 2002;10(2):80-5.

9. Vadalà A, lorio R, De Carli A, Argento G, Di Sanzo V, Conteduca F, et al. The effect of accelerated, brace free, rehabilitation on bone tunnel enlargement after ACL reconstruction using hamstring tendons: A CT study. Knee Surg Sports Traumatol Arthrosc. 2007;15(4):365-71.

10. Fauno $P$, Kaalund $S$. Tunnel widening after hamstring anterior cruciate ligament reconstruction is influenced by the type of graft fixation used: A prospective randomized study. Arthroscopy. 2005;21(11):1337-41.

11. Garofalo R, Mouhsine E, Chambat $P$, Siegrist $O$. Anatomic anterior cruciate liga- ment reconstruction: the two-incision technique. Knee Surg Sports Traumatol Arthrosc. 2006;14(6):510-6.
12. Pádua VBC, Maldonado H, Vilela JCR, Provenza AR, Monteiro C, Oliveira Neto HC. Estudo comparativo da reconstrução do LCA com o posicionamento anatômico dos túneis entre o tendão patelar e os tendões flexores. Rev Bras Ortop. 2012;47(1):50-6.

13. Hwang DH, Shetty GM, Kim JI, Kwon JH, Song JK, Muñoz M, et al. Does Press-Fit Technique Reduce Tunnel Volume Enlargement After Anterior Cruciate Ligament Reconstruction With Autologous Hamstring Tendons? A Prospective Randomized Computed Tomography Study. Arthroscopy. 2013;29(1):83-8.

14. Webster KE, Feller JA, Hameister KA. Bone tunnel enlargement following anterior cruciate ligament reconstruction: a randomised comparison of hamstring and patellar tendon grafts with 2-year follow-up. Knee Surg Sports Traumatol Arthrosc. 2001;9(2):86-91.

15. Fink C, Zapp M, Benedetto KP, HackI W, Hoser C, Rieger M. Tibial tunnel enlargement following anterior cruciate ligament reconstruction with patellar tendon autograft. Arthroscopy. 2001;17(2):138-43.

16. Marchant MH Jr, Willimon SC, Vinson E, Pietrobon R, Garrett WE, Higgins LD. Comparison of plain radiography, computed tomography, and magnetic resonance imaging in the evaluation of bone tunnel widening after anterior cruciate ligament reconstruction. Knee Surg Sports Traumatol Arthrosc. 2010;18(8):1059-64.

17. Barth J, Akritopoulos P, Graveleau N, Barthelemy R, Toanen C, Saffarini M. Efficacy of Osteoconductive Ceramics in Bioresorbable Screws for Anterior Cruciate Ligament Reconstruction: A Prospective Intrapatient Comparative Study. Orthop J Sports Med. 2016;4(5):2325967116647724.

18. Robinson J, Huber C, Jaraj P, Colombet P, Allard M, Meyer P. Reduced bone tunnel enlargement post hamstring ACL reconstruction with poly-L-lactic acid/ hydroxyapatite bioabsorbable screws. Knee. 2006;13(2):127-31.

19. Wang JH, Lee ES, Lee BH. Paradoxical tunnel enlargement after ACL reconstruction with hamstring autografts when using -TCP containing interference screws for tibial aperture fixation- prospectively comparative study. BMC Musculoskelet Disord. 2017;18(1):398.

20. Yanagisawa S, Kimura M, Hagiwara K, Ogoshi A, Nakagawa T, Shiozawa H, et al. The remnant preservation technique reduces the amount of bone tunnel enlargement following anterior cruciate ligament reconstruction. Knee Surg Sports Traumatol Arthrosc. 2018;26(2):491-9. 